\title{
Localization of prolactin receptor in the dorsal and ventral skin of the frog (Rana ridibunda)
}

\author{
Meliha Sengezer Inceli ${ }^{1}$, Engin Kaptan $^{1}$, Serap Sancar $^{1}$, Osman Murathanoglu ${ }^{1}$ \\ \& Songul Suren CASTILLO ${ }^{2}$ \\ ${ }^{1}$ Istanbul University, Faculty of Science, Department of Biology, Zoology Section, 34134 Vezneciler, Istanbul, Turkey; \\ e-mail:melis@istanbul.edu.tr \\ ${ }^{2}$ Institut de Biologia Evolutiva (CSIC-UPF) CMIMA. Passeig Maritim de Barceloneta, 37, 08003 Barcelona, Spain
}

\begin{abstract}
The dorsal and ventral skin in amphibians plays an important role in osmoregulation. Prolactin hormone is involved in regulation of amphibian skin functions, such as water and electrolyte balance. Therefore, amphibians may be useful as a model for determining the sites of the prolactin receptor. In this study, prolactin receptor was detected in frog dorsal and ventral skin using immunohistochemical staining method. Prolactin receptor immunoreactivity was localized in all epidermal layers except stratum corneum of dorsal skin epidermis, stratum germinativum layer of ventral skin epidermis, myoepithelial cells, secretory epithelium and secretory channel cells of granular glands in both skin regions. The mucous glands and secretory granules of granular glands did not show immunoreactivity for the prolactin receptor. According to our immunohistochemical results, the more widespread detection of prolactin receptor in dorsal skin epidermis indicates that prolactin is more effective in dorsal skin. Presence of prolactin receptors in epidermis points out its possible osmoregulatory effect. Moreover, detection of receptor immunoreactivity in various elements of poison glands in the dermis of both dorsal and ventral skin regions suggests that prolactin has a regulatory effect in gland functions.
\end{abstract}

Key words: prolactin receptor; frog skin; immunohistochemistry; Rana ridibunda

\section{Introduction}

The skin plays an important role in homeostasis of the amphibian, regulating respiratory gases, salts and water exchange, and acting as an interface between the organism and its external environment (Slominski \& Wortsman 2000; Brizzi et al. 2002).

Amphibian skin comprises an outer epidermal layer and underlying dermal layer. The epidermis is a stratified epithelium organized in four cells layers; the innermost stratum basal or germinativum, the stratum spinosum, stratum granulosum and the outermost stratum corneum. The dermis is composed of connective tissue and contains various connective tissue cells, smooth muscle cells, chromatophores, multicellular simple alveolar glands, diffuse blood vessels and nerves. Two types of skin glands, mucous glands and granular (serous) glands, are commonly found in the skin of adult amphibians. The mucus produced in mucous glands is homogenous and slimy, and it is composed principally of mucopolysaccharides, which maintain skin moisture and provide skin protection from damage through prolonged contact with water, and also reduce water loss through evaporation (Li et al. 2006). Granular glands synthesize considerable amounts of bioactive peptides and aromatic biogenic amines (Nakajima 1981; Roseghini et al. 1989) that help protect the organism from the enemies (Toledo et al. 1992) and reg- ulate the water balance of the skin (Delfino et al. 1996).

In amphibians, the dorsal and ventral skin plays a major role in osmoregulation (Uchiyama \& Konno 2006). Some amphibians, such as tree frogs, have limited water resources, and a primary characteristic of such species is to absorb water efficiently through the ventral skin. Therefore, the ventral skin of terrestrial toads has a higher permeability to water than more aquatic species (Bentley 2002). Amphibian skin is known to transport sodium $\left(\mathrm{Na}^{+}\right)$actively from the epidermal to the dermal side, and some hormones can also control this $\mathrm{Na}^{+}$transport across epithelial tissue (Takada \& Hokari 2007). This system of transport may be involved in the adaptation of the adult amphibian to a terrestrial habitat via changes in osmoregulation (Uchiyama \& Konno 2006).

Prolactin (PRL) is primarily synthesized and secreted by the pituitary gland and has also been found in numerous other cells and tissues of vertebrates. PRL bound to the PRL receptor (PRLR), triggers intracellular signalling pathways to express a physiological response of target tissue or cells (Bole-Feysot et al. 1998). More than 200 effects of prolactin have been documented on growth, reproduction, osmoregulation, and immunologic response (Schardin \& Anzenberger 1999). In amphibians, prolactin participates in processes regulating growth, metamorphosis, osmoregulation and re- 
production (Iwata et al. 2000; Yamamoto et al. 2000; Takada \& Hokari 2007). Studies with exogenous PRL treatment in amphibians have shown changes in skin permeability (Brown et al. 1991; Takada 2005; Takada \& Hokari 2007), and in skin morphology and secretory activity (Dent 1975; Hoffman \& Dent 1978; Singhas \& Ward 1993).

The existence of prolactin receptor has been shown in different organs of various animals (Bole-Feysot et al. 1998). In adult amphibian skin, PRLR has been detected by using different methods (D'Istria et al. 1987; Muccioli et al. 1989; Yamamoto et al. 2000; Li et al. 2006), although there is a lack of knowledge concerning localization of PRLR in the skin components. In this study, by using an immunohistochemical technique, we have investigated the localization and distribution of PRLR in the dorsal and ventral skin of Rana ridibunda Pallas, 1771 and discussed possible functions of PRL in different skin regions of the body.

\section{Material and methods}

Five adult male frogs (Rana ridibunda) were collected from the Meric River of Edirne. The animals were anesthetized by submerging into 1\% solution of MS-222 (Sigma A5040). After decapitation, dorsal and ventral skin fragments, approximately $1 \mathrm{~cm}^{2}$, were removed and fixed in Bouin's solution for $24 \mathrm{~h}$. After dehydration, samples were embedded in paraffin and $4 \mu \mathrm{m}$ thick sections were obtained. The sections were stained with hematoxylin-eosin and periodic acid-Schiff (PAS) techniques.

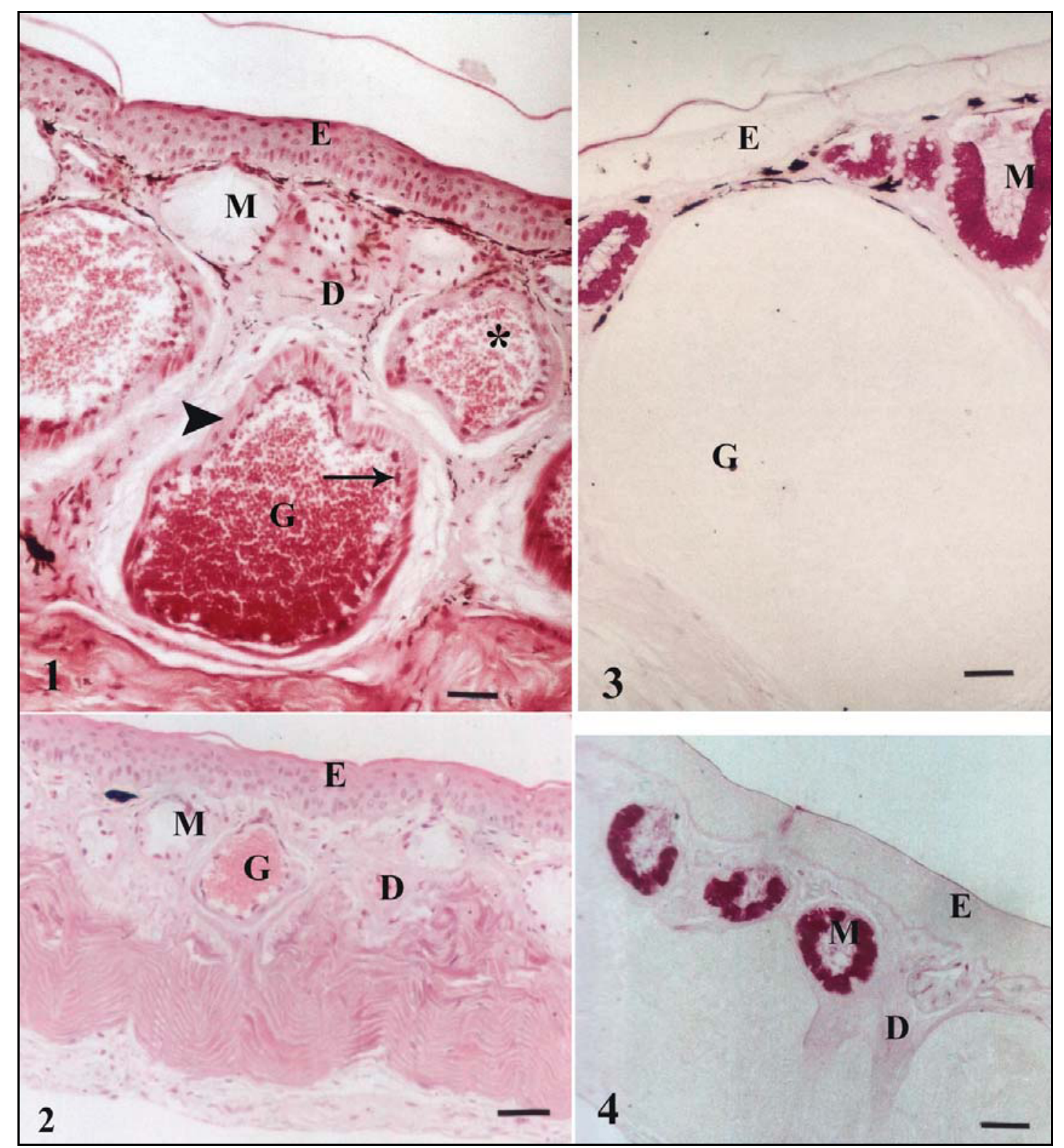

Figs 1-4. 1 - General view of the dorsal skin stained with hematoxylin and eosin. 2 - General view of the ventral skin stained with hematoxylin and eosin. 3 - General view of the dorsal skin stained with Periodic acid-Schiff. 4 - General view of the ventral skin stained with Periodic acid-Schiff. Epidermis (E), dermis (D), mucous gland (M), granular gland (G), arrow: secretory epithelium, arrowhead: myoepithelial sheath, ${ }^{*}$ secretory granules. Scales $50 \mu \mathrm{m}$. 
PRLR was detected in the sections using a horseradish peroxidase-diaminobenzidine (HRP-DAB) immunohistochemical staining method. After deparaffinization, endogenous peroxidase activity was blocked at room temperature for 20 min (Hydrogen Peroxide Block, Diagnostic BioSystems C825), prior to incubation in mouse anti-prolactin Ab-1 receptor monoclonal primary antibody (Neomarkers MS1338-R7) for 3 days at $4^{\circ} \mathrm{C}$. This was followed by incubation in anti-mouse biotinylated secondary antibody (Diagnostic BioSystems C723) in the dark at $35^{\circ} \mathrm{C}$ for 20 min and subsequent incubation in streptavidin-biotin peroxidase complex (Diagnostic Biosystems C728) (in the dark at $35^{\circ} \mathrm{C}$ for $20 \mathrm{~min}$ ) prior to visualization with a DAB chromogen substrate solution (Diagnostic BioSystems K007) in the dark at room temperature for $30 \mathrm{~min}$. Sections were washed with phosphate buffer $(0.01 \mathrm{M}, \mathrm{pH}: 7.2)$ three times between the various steps of the procedure. For negative controls, the primary antibody was replaced by phosphate buffer $(0.01$ $\mathrm{M}, \mathrm{pH}$ 7.2) and human breast carcinoma was used for positive controls.

\section{Results}

\section{Histological observations}

The epidermis of dorsal and ventral skin regions consisted of 4-5 layers of cells, which overlay the dermis. Mucous glands were located in the dermis in close proximity to the epidermis. The inner surfaces of secretory units of the mucous glands were lined with cubical cells, and myoepithelial sheaths were not very obvious (Figs 1, 2). The cytoplasm of the mucous gland cells and luminal material appeared fibrillar and was PASpositive (Figs 3, 4). The granular glands of the skin were larger than the mucous glands. Their secretory epithelium was syncytial and the myoepithelial cells were more easily seen. The lumina of the granular glands contained elliptical and spherical secretory granules, which were eosinophilic (Figs 1, 2) and PAS-negative (Fig. 3). The mucous and granular glands of the ventral skin were smaller than in the dorsal skin and the granular glands were sparser in the ventral skin. The dermis of the ventral skin was also very thin (Figs 2,4).

\section{Immunohistochemical observations}

PRLR immunoreactivity was observed in all epidermal layers apart from the stratum corneum of the dorsal skin epidermis (Figs 5,6) and only in stratum germinativum layer of ventral skin epidermis (Fig. 7). When two different skin regions were compared with each other, PRLR immunoreactivity was more widespread in dorsal skin epidermis (Figs 5-7). The immunoreactivity in the other components of the skin was present in myoepithelial cells, the secretory epithelium of granular glands (Figs 5, 7-9) and the secretory channel cells of granular glands (Fig. 9) in both skin regions, although mucous glands and secretory granules of granular glands were not PRLR immunoreactive (Figs 5-9).

\section{Discussion}

In previous studies, PRLR has been detected in the skin of several amphibian species. PRLR has been observed in skin of Xenopus laevis Daudin, 1802 and Rana esculenta L., 1758 by using ${ }^{125}$ I-PRL binding (D'Istria et al. 1987; Muccioli et al. 1989). In R. esculenta, PRL binding to skin fractions was generally high in the month of October, whereas the lowest value was found during the summer season (D'Istria et al. 1987). In X. laevis, the values of PRL specific binding to the membranes from the skin were decreased by dehydration of the animals (Muccioli et al. 1989). Yamamoto et al. (2000) investigated the tissue distribution of PRLR mRNA in adult and larval $X$. laevis by northern hybridization. In adult tissues, high level expression was found in the lung, heart, brain, thymus and skin, and low level in the oviduct, kidney and spinal cord. In larval tissue, PRLR mRNA was expressed in the brain and tail from premetamorphosis and the level increased toward late metamorphosis. Li et al. (2006) showed by western blot analysis that temperature and humidity alter PRLR protein level in the skin of Bufo bankorensis Barbour, 1908 and Bufo melanostictus Schneider, 1799. These finding clearly indicate that PRL is important in the adaptation of amphibians to different environmental conditions.

In the mentioned studies, only the presence of PRLR has been detected in the amphibian skins by using different methods, although these studies do not show the location of the PRLR in the skin components such as epidermis, dermis, mucous gland, granular gland (secretory epithelium, myoepithelial cell, duct) etc. In this study, we have localized the distribution of PRLR in the dorsal and ventral skin components of $R$. ridibunda by using immunohistochemical technique.

Some adult amphibians adapt to both terrestrial and aquatic environments, while others are dependent on water only during their mating season. In some cases, various species are barely dependent on water (Bani et al. 1985). Regulation of salt and water balance for homeostasis is essential for organisms. As a consequence of their dependence on water, amphibians regulate water and ion concentrations in their body via a cooperative action of three osmoregulatory organs, namely the skin, urinary bladder and kidneys (Shane et al. 2006; Uchiyama \& Konno 2006). In amphibians, osmoregulation is controlled primarily by four hormonal systems: hypothalamo-neurohypophysial system, reninangiotensin-aldosterone system (RAS), hypothalamopituitary-adrenal cortex system and natriuretic peptides system (NPs). Other hormones with osmoregulatory functions such as hydrins, PRL, insulin and guanylins as well as the autonomic nervous system also have a role in osmoregulation (Acher et al. 1997; Uchiyama \& Konno 2006).

Since amphibian skin is an useful model for determining osmoregulatory effect, there are many studies related with to the subject. It has been reported that $\mathrm{Na}^{+}$transport was stimulated (Takada \& Kasai 2003), whereas basolateral $\mathrm{K}^{+}$current was inhibited (Takada 2005 ) in isolated ventral pelvic skin patch treated with PRL in a tree frog (Hyla arborea japonica Nikolskii, 


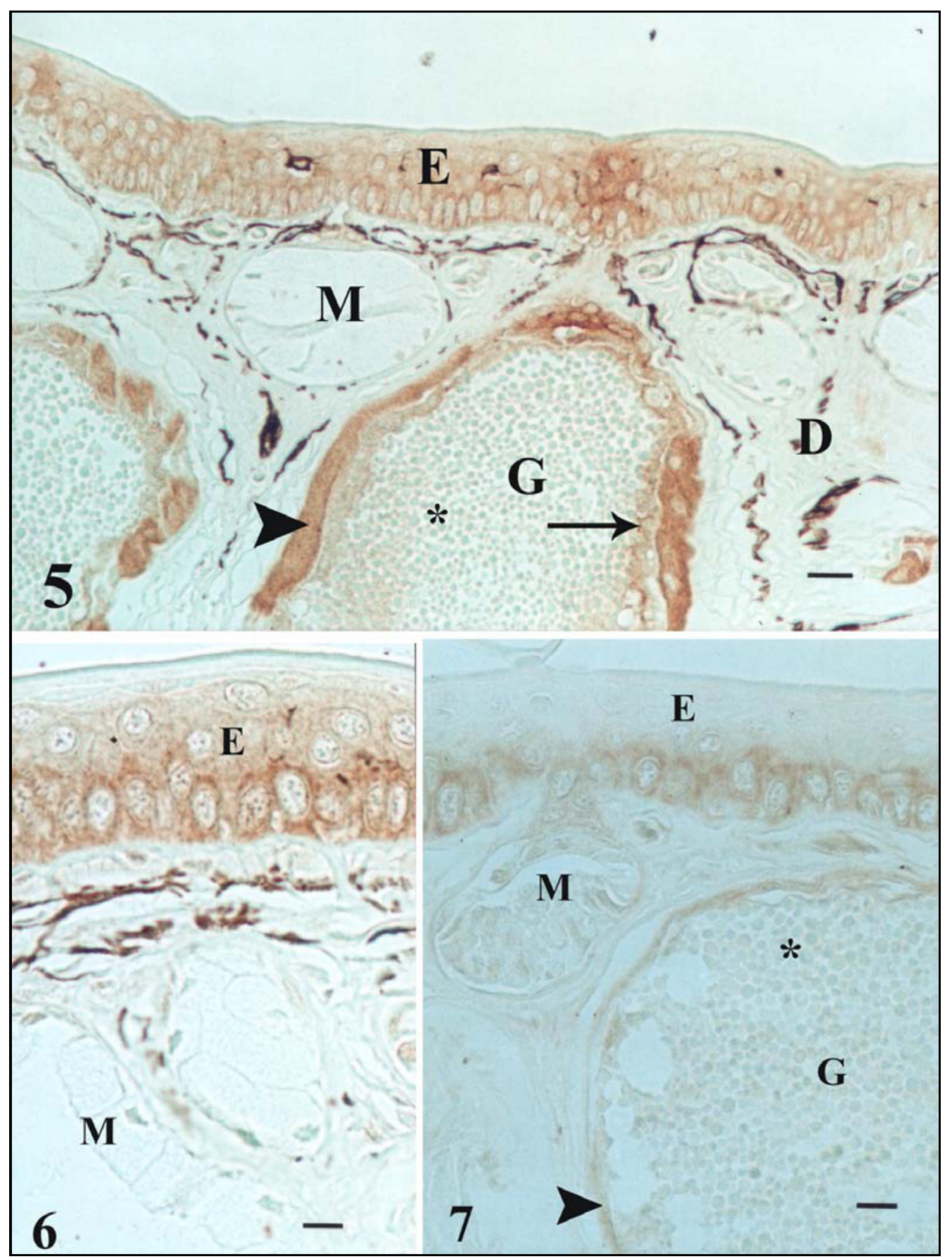

Figs 5-7. 5, 6- Prolactin receptor immunoreactivity in sections of the dorsal skin. 7- Prolactin receptor immunoreactivity in epidermis of the ventral skin. Epidermis (E), dermis (D), mucous gland (M), granular gland (G), arrow: secretory epithelium, arrowhead: myoepithelial sheath, ${ }^{*}$ secretory granules. Scales $50 \mu \mathrm{m}$.

1918). In adult bullfrog (Rana catesbeiana Shaw, 1802), PRL is involved in the regulation of $\mathrm{Na}^{+}$transport from the apical to the basolateral side across the skin (Takada \& Hokari 2007). In addition, application of PRL in newts decreased the osmotic permeability of the skin (Takada \& Komazaki 1988; Brown et al. 1991).

External PRL treatment caused changes in expression of the structural and secretory epidermal glycoconjugates in red spotted-newt (Singhas \&Ward 1993). Faszewski \& Kaltenbach (1995) suggested that different glycoconjugate patterns in dorsal and ventral skin of the terrestrial horned frog Ceratophrys ornata Bell,
1843 may be associated with the regulation of water balance, and other authors have reported that glycoconjugates in the epidermis of Rana perezi Seoane, 1885 and Pleurodeles waltii Michahelles, 1830 may be involved in epidermal permeability (Bueno et al. 1981; Navas et al. 1987).

Based upon the mentioned data on the osmoregulatory role of PRL, it was not surprising for us to localize PRLR in the epidermis of $R$. ridibunda. However, we found that PRLR immunoreactivity was more frequently observed in the epidermal dorsal skin than in the ventral skin. These different immunoreactive pat- 


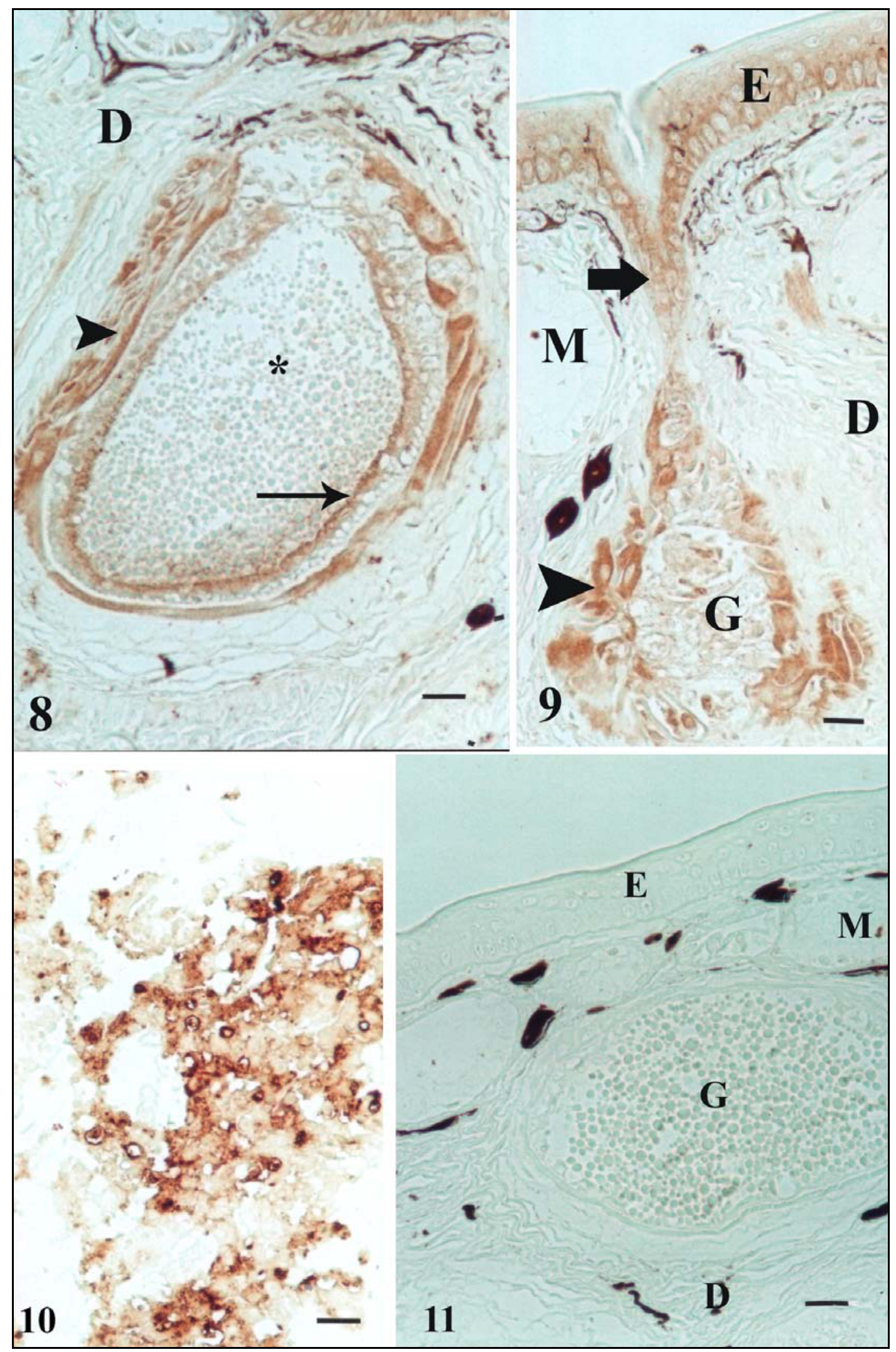

Figs 8-11. 8, 9- Prolactin receptor immunoreactivity in sections of the dorsal skin. 10 - Prolactin receptor immunoreactivity in human breast carcinoma (positive control). 11 - The negative control. Epidermis (E), dermis (D), mucous gland (M), granular gland (G), arrowhead: myoepithelial sheath, arrow: secretory epithelium * secretory granules. Bold arrow indicates duct of granular gland. Scales $50 \mu \mathrm{m}$.

terns between the dorsal and ventral skin suggest that permeability in the skin of both regions may differ.
Nonetheless, no PRLR was observed in the outermost (stratum corneum) layer of the dorsal skin epidermis. It 
is known that the stratum corneum is composed of keratinized cells, and that the synthetic capabilities of the cornified cells during the keratinization process are terminated upon autolysis of the cellular organelles (Junqueria \& Carneiro 2003). Therefore, it is possible that receptor production ceases prior to the cell death.

Amphibian skin contains a very thin stratum corneum that is poorly keratinized (Lillywhite 2006). Therefore, the skin is protected and kept moist by the mucus produced by mucous glands ( $\mathrm{Li}$ et al. 2006). In studies with red-spotted newt, it was shown that PRL alters the secretion of mucous glands (Hoffman \& Dent 1978; Singhas \& Ward 1993), and in this regard the capability of mucous glands to respond to the external PRL application indicates the presence of PRLR in the gland cells. However, we did not observe PRLR in the mucous glands of $R$. ridibunda skin, and as thus, we can postulate that these glands are not influenced by PRL.

Secretion granules are synthesized in the secretory epithelium. Storage and maturation of serous product occurs within the syncytical cytoplasm (Delfino 1991). Singhas \& Ward (1993) showed that glycoconjugates containing fucose and $\mathrm{N}$-acetylgalactosamine residues within granular glands reduced after treatment with PRL of red spotted newts. PRLR, found in the secretory epithelium of granular glands, indicates that this hormone may regulate the composition of the granular gland product.

The synthesized secretion material initially accumulates in the lumen of the gland and then is released onto the skin via contraction of the myoepithelial cells. Moreover, these contractile cells perform active bulktransport processes of substances relevant to secretory unit metabolism (Bani \& Delfino 1990). We have detected PRLR immunoreactivity in the myoepithelial cells of granular glands. The function of PRL in these myoepithelial cells is unknown, but it is certainly linked to the functions of this cell.

We have found that poison gland ducts were also PRLR immunoreactive. Secretory epithelium of granular glands becomes fully degraded following the secretion, and cytoplasmic material is ejected out of the gland along with the secretion. Secretory epithelium is regenerated for the next secretion cycle, by proliferation and cytodifferentiation of stem cells in neck region of the gland (Delfino 1980). It is probable that the reported proliferative effect of PRL (Hoffman \& Dent 1977; Bole-Feysot et al. 1998) contributes to the gland rehabilitation after secretion. In summary, the presence of PRLR in various structural elements of the granular glands may be an indication of the necessity of PRL in the function of these glands.

In the current study, PRLR has been detected in epidermis and various structural elements of granular glands of $R$. ridibunda skin. According to our immunohistochemical results, the more widespread detection of prolactin receptor in dorsal skin epidermis indicates that prolactin is more effective in the dorsal skin. The presence of prolactin receptors in the epidermis points out its possible osmoregulatory effect. Moreover, the observation of receptor immunoreactivity in various elements of granular glands in the dermis of both skin regions indicates a regulatory role for PRL in the gland functions.

\section{Acknowledgements}

This work was supported by the Research Fund of Istanbul University, Project Number: 163/15012004.

\section{References}

Acher R., Chauvet J. \& Rouille Y. 1997. Adaptive evolution of water homeostasis regulation in amphibians: Vasotocin and hydrins. Biol. Cell 89: 283-291. DOI 10.1016/S02484900(97)83380-1

Bani G., Cecchi R. \& Bianchi S. 1985. Skin morphology in some amphibians with different ecological habits. A light and electron microscopic study. Z. Mikrosk. Anat. Forsch. 99: 455474.

Bani G. \& Delfino G. 1990. Ultrastructure of the myoepithelial cells of the cutaneous glands in several amphibian species. Biomed Res. 1: 73-83.

Bentley P.J. 2002. The Amphibia; Endocrines and Osmoregulation. A Comparative Account in Vertebrates, $2^{\text {nd }}$ Ed., Vol. 1 (Chapter 6), pp. 155-186.. In: Bradshaw S.D., Burggren W., Heller H.C., Ishii S., Langer H., Neuweiler G. \& Randall D.J. (eds), Zoophysiology, Vol. 39, Springer-Verlag, Berlin, Heidelberg,

Bole-Feysot C., Goffin V., Edery M., Binart N. \& Kelly P.A. 1998. Prolactin (PRL) and its receptor: Actions, signal transduction pathways and phenotypes observed in PRL receptor knockout mice. Endocr. Rev. 19: 225-268. DOI 10.1210/er.19.3.225

Brizzi R., Delfino G. \& Pellegrini R. 2002. Specialized mucous glands and their possible adaptive role in the males of some species of Rana (Amphibia, Anura). J. Morphol. 254: 328341. DOI 10.1002/jmor.10039

Brown S.C., Brown P.S., Yamamoto K., Matsuda K. \& Kikuyama S. 1991. Amphibian prolactins: Activity in the eft skin transepithelial potential bioassay. Gen. Comp. Endocr. 82: 1-7. DOI 10.1016/0016-6480(91)90289-I

Bueno C., Navas P., Aijon J. \& Lopez-Campos J.L. 1981. Glycoconjugates in the epidermis of Pleurodeles waltii. J. Ultrastruct. Res. 77: 354-359.

Delfino G. 1980. L'attivita rigeneratrice del tratto intercalare nelle ghiandole granulose cutanee dell'Ululone Bombina variegate pachypus (Bonaparte) (Anfibio, Anuro, Discoglosside): Studio sperimentale al microscopico elettronico. Arch. Ital. Anat. Embriol. 85: 283-310.

Delfino G. 1991. Ultrastructural aspects of venom secretion in anuran cutaneous glands, pp. 777-798. In: Tu A.T. (ed.), Handbook of Natural Toxins. Reptile Venoms and Toxins, Marcel Dekker, New York.

Delfino G., Brizzi R. \& Melis G. 1996. Merocrine secretion from serous cutaneous glands in Rana esculenta complex and Rana iberica. Alytes 13: 179-192.

Dent J.N. 1975. Integumentary effects of prolactin in the lower vertebrates. Am. Zool. 15: 923-935.

D'Istria M., Fasano S. \& Delrio G. 1987. Prolactin receptors in the male Rana esculenta. Gen. Comp. Endocr. 68: 6-11. DOI 10.1016/0016-6480(87)90053-0

Faszewski E.E. \& Kaltenbach J.C. 1995. Histology and lectinbinding patterns in the skin of the terrestrial horned frog Ceratophrys ornate. Cell Tissue Res. 281: 169-177. DOI 10.1007/BF00307971

Hoffman C.W. \& Dent J.N. 1977. Hormonal effects on mitotic rhythm in the epidermis of the red-spotted newt. Gen. Comp. Endocr. 32: 512-521.

Hoffman C.W. \& Dent J.N. 1978. The morphology of the mucous gland and its responses to prolactin in the skin 
of the red-spotted newt. J. Morphol. 157: 79-98. DOI 10.1002/jmor.1051570106

Iwata T., Toyoda F., Yamamoto K. \& Kikuyama S. 2000. Hormonal control of urodele reproductive behavior. Comp. Biochem. Physiol. 126 B: 221-229. DOI 10.1016/S03050491(00)00200-5

Junqueria L.C. \& Carneiro J. 2003. Basic Histology. McGraw-Hill Companies Inc, New York, 372 pp.

Li K.W., Lee D.N., Huang W.T. \& Weng C.F. 2006. Temperature and humidity alter prolactin receptor expression in the skin of toad (Bufo bankorensis and Bufo melanostictus). Comp. Biochem. Physiol. 145 A: 509-516. DOI 10.1016/j.cbpa.2006.08.044

Lillywhite H.B. 2006. Water relations of tetrapod integument. J. Exp. Biol. 209: 202-226. DOI 10.1242/jeb.02007

Muccioli G., Guardabassi A., Pattono P. \& Genazzani E. 1989. Further study on the changes in the concentration of prolactin-binding sites in different organs of Xenopus laevis male and female, kept under dry conditions and then returned to water (their natural habitat). Gen. Comp. Endocr. 74: $411-417$.

Nakajima T. 1981. Active peptides in amphibian skin. Trends Pharmacol. Sci. 2: 202-205.

Navas P., Villalba J.M., Buron, M.I. \& Herdugo G.G. 1987. Lectins as markers for plasma membrane differentiation of amphibian keratinocytes. Biol. Cell 60: 225-234.

Roseghini M., Erspamer G.F., Severini C. \& Simmaco M. 1989. Biogenic amines and active peptides in extracts of the skin of thirty-two European amphibian species. Comp. Biochem. Physiol. 94 C: 455-460.

Schardin C. \& Anzenberger G. 1999. Prolactin, the hormone of paternity. News Physiol. Sci. 14: 223-231.

Shane M.A., Nofziger C. \& Blazer-Yost B.L. 2006. Hormonal regulation of the epithelial $\mathrm{Na}^{+}$channel: From amphibians to mammals. Gen. Comp. Endocr. 147: 85-92. DOI 10.1016/j.ygcen.2005.11.010
Singhas C.A. \& Ward D.L. 1993. Prolactin alters the expression of integumental glycoconjugates in the red-spotted newt, $\mathrm{No}$ tophthalmus viridescens. Anat. Rec. 236: $537-546$.

Slominski A. \& Wortsman J. 2000. Neuroendocrinology of the skin. Endocr. Rev. 21: 457-487.

Takada M. 2005. Prolactin, an activator of epithelial $\mathrm{Na}^{+}$channel, inhibits basolateral $\mathrm{K}^{+}$channels in adult tree frog skin. Zool. Sci. 22: 95-100.

Takada M. \& Hokari S. 2007. Prolactin increases $\mathrm{Na}^{+}$transport across adult bullfrog skin via stimulation of both $\mathrm{ENaC}$ and $\mathrm{Na}^{+} / \mathrm{K}^{+}$-pump. Gen. Comp. Endocr. 151: 325-331. DOI 10.1016/j.ygcen.2007.01.040

Takada M. \& Kasai M. 2003. Prolactin increases open-channel density of epithelial $\mathrm{Na}^{+}$channel in adult frog skin. J. Exp. Biol. 206: 1319-1323. DOI 10.1242/jeb.00266

Takada M. \& Komazaki S. 1988. Effect of prolactin on transcutaneous $\mathrm{Na}$ transport in the Japanese newt, Cynops pyrrhogaster. Gen. Comp. Endocr. 69: 141-145. DOI 10.1016/ 0016-6480(88)90063-9

Toledo R.C., Jared C. \& Brunner A.Jr. 1992. Morphology of the large granular alveoli of the parotid glands in the toad (Bufo ictericus) before and after compression. Toxicon 30: 745-753. DOI 10.1016/0041-0101(92)90008-S

Uchiyama M. \& Konno N. 2006. Hormonal regulation of ion and water transport in anuran amphibians. Gen. Comp. Endocr. 147: 54-61. DOI 10.1016/j.ygcen.2005.12.018

Yamamoto T., Nakayama Y., Tajima T., Abe S. \& Kawahara A. 2000. Cloning of a cDNA for Xenopus prolactin receptor and its metamorphic expression profile. Dev. Growth Differ. 42: 167-174. DOI 10.1046/j.1440-169x.2000.00496.x

Received March 25, 2009 Accepted November 2, 2009 